
\title{
25 Research Soure \\ Early Kinetics of Calprotectin in Plasma Following Inguinal Hernia Surgery
}

Kristina Sejersen ( $\nabla$ kristina.sejersen@unilabs.com )

Uppsala University: Uppsala Universitet https://orcid.org/0000-0001-7371-9671

Aleksandra Havelka

Karolinska Institutet

Pearl Sanchez Salas

Region Gävleborg: Region Gavleborg

Anders Larsson

Uppsala University: Uppsala Universitet

\section{Research}

Keywords: Calprotectin, kinetics, inflammation, inguinal hernia surgery

Posted Date: July 8th, 2021

DOl: https://doi.org/10.21203/rs.3.rs-669421/v1

License: (9) This work is licensed under a Creative Commons Attribution 4.0 International License.

Read Full License

Version of Record: A version of this preprint was published at Innate Immunity on February 1st, 2022. See the published version at https://doi.org/10.1177/17534259211069635. 


\section{Abstract}

Background: Calprotectin is one of the most abundant proteins of neutrophil granulocytes. It is released upon activation of neutrophils and is considered as a sensitive and clinically useful marker for neutrophil mediated inflammation, including bacterial infections. However, the early kinetics of calprotectin activation in humans following inflammatory activation has hitherto been unknown.

Aim: The aim of the present study was to determine the early phase of the kinetics of calprotectin in plasma following a standardized temporary mild inflammatory response, using uncomplicated inguinal hernia surgery as a model.

Methods: The study cohort consisted of 17 patients (16 men, age 41-79, 1 woman, age 54), undergoing elective surgery for uncomplicated hernia with laparoscopic $(n=5)$ or open surgery $(n=12)$, and without signs of inflammatory disease (C-reactive protein (CRP) $<5 \mathrm{mg} / \mathrm{L}$ ) at entry of study. Calprotectin and inflammatory markers CRP, interleukin-6 (IL-6), tumor necrosis factor-alpha (TNF-a), and procalcitonin were measured in plasma at start of surgery (0), and following $2,4,6$, and 24-36 h after inguinal surgery.

Results: Values of calprotectin increased significantly $(\mathrm{p}=0.02532)$ at $2 \mathrm{~h}$ following surgery (mean 0.99 $\mathrm{mg} / \mathrm{L}$ ) from the lowest basal levels (mean $0.58 \mathrm{mg} / \mathrm{L}$ ), and continued to increase to reach highest level at 24-36 $\mathrm{h}$ (mean $1.58 \mathrm{mg} / \mathrm{L}$ ) postsurgery. This contrasts to IL-6 and CRP, for which an elevation was found first later, with a transient elevation at $4 \mathrm{~h}$ postsurgery for IL-6 ( $\mathrm{p}=0.03098)$, and a later elevation for CRP in the 24-36 h postsurgery samples $(p=0.00124)$. No significant increase was seen at any analysed time point postsurgery for TNF-a, or procalcitonin.

Conclusion: Calprotectin levels in plasma were rapidly elevated (within $2 \mathrm{~h}$ following mild inflammatory response associated with inguinal hernia surgery and continued to increase at later time points (24-36 h). Increase of calprotectin was observed several hours prior to increase in IL-6 or CRP. However, during the first $24 \mathrm{~h}$ the levels induced by the mild inflammatory response caused by inguinal hernia surgery were not significantly exceeding the normal reference range, suggesting that calprotectin can be useful for early detection of postsurgical infections.

\section{Background}

Infectious diseases are common and constitute a major global cause of death [1]. Early diagnosis is clinically important to reduce delay from symptom onset to initiation of adequate medical therapy in order to reduce risks of protracted infection, sepsis/mortality, and their late sequelae [2], and also to avoid improper use of antibiotics. The latter is highlighted by the increasing general problem with antibiotic resistance [3,4]. Biomarkers which can aid in differentiating between early stage of bacterial and viral infections may thus be useful in contributing to use of antibiotics restricted to situations with high risk of bacterial cause of a suspected infection [2]. 
In clinical practice, early diagnosis of a bacterial infection which require antibiotic treatment is most frequently based on observation of clinical symptoms, supplemented with leukocyte counts and/or Creactive protein (CRP) measurement in blood. However, these clinical diagnostic measures result in missing bacterial infections in a considerable proportion of patients, approximately $40 \%$ [5]. The neutrophil protein calprotectin has been suggested to serve as a biomarker of potential use to detect bacterial infections at an early stage, and was recently reported to distinguish bacterial respiratory infections from those caused by virus or mycoplasma [6]. Neutrophils are among the first cells to invade inflammatory sites, and contribute to pathogen killing through mechanisms including production of reactive oxygen species by the nicotinamide adenine dinucleotide phosphate-oxidase (NADPH oxidase), and release of cytotoxic products during the degranulation process and formation of neutrophil extracellular traps. Neutrophils can secrete a considerable number of substances important to attract and other immune cells and modulate their effect [7]. Activation of neutrophils has for long been attributed solely to the presence of pathogens, but later studies demonstrated that it can also be induced by the endogenous factors damage associated molecular pattern (DAMPs) or alarmins [8]. DAMPs are released by activated phagocytes such as neutrophils and monocytes $[9,10]$. Calprotectin, a member of the DAMPs, is abundantly expressed in the cytosol, constituting around $40 \%$ of total proteins of circulating neutrophils, and participates in both intra- and extracellular activities.

Calprotectin is known to regulate intracellularly NADPH oxidase activity [11, 12], the major source of reactive oxygen species (ROS) in neutrophils. High concentrations of Calprotectin extracellularly is found at local sites of inflammation or in the serum of patients with inflammatory diseases (e.g., rheumatoid arthritis (RA), cystic fibrosis, or inflammatory bowel disease (IBD)) $[10,13,14]$ and represents a sensitive inflammation biomarker strongly associated with disease level [15]. Furthermore, studies have demonstrated calprotectin to be a promising biomarker for sepsis $[16,17]$. However, the early kinetics of calprotectin in blood/plasma in clinical situations including inflammatory/neutrophil activation has hitherto been unknown. To this end the present study was undertaken in order to reveal the early kinetics of calprotectin in plasma following elective surgery for uncomplicated hernia as a clinical model for inflammatory response [18], including neutrophil activation [19], and to compare this kinetics with that for the inflammatory markers CRP, interleukin-6 (IL-6), tumor necrosis factor-alpha (TNF-a), and procalcitonin.

\section{Materials And Methods}

\section{Patients}

20 patients were initially included in the study. As inclusion criteria, adults undergoing elective surgery for uncomplicated hernia with laparoscopic or open surgery, and without signs of inflammatory disease $(\mathrm{CRP}<5 \mathrm{mg} / \mathrm{L})$ at entry of study were eligible for participation. For inclusion in the study, patients should give blood samples just before $(<0.5 \mathrm{~h}$ ) surgery (basal level) and at least one time postsurgery. Exclusion criteria were CRP $\geq 5 \mathrm{mg} / \mathrm{L}$, white blood cell (WBC) count $>9.0 \times 10 \otimes / \mathrm{L}$ ( $\geq 18$ years), known active RA, IBD or other active inflammatory disease known at time for inclusion. In addition, children (age $<18$ years) and patients who could not give informed consent were excluded from the study. The patients were 
admitted to Department of Surgery, Gävle Hospital, Region Gävleborg, Sweden. Blood samples were collected in BD Vacutainer ${ }^{\mathrm{TM}}$ lithium heparin tubes without a gel for plasma separation, immediately before start of the surgery, and 2, 4, 6 and 24-36 h after the start of surgery. The blood samples were drawn either at surgery or in the postoperative ward. For the last sample patients needed to come back from home to the hospital with taxi. All blood samples were sent directly after blood sampling to the hospital laboratory, centrifuged within $2 \mathrm{~h}$ from venipuncture at $1890 \mathrm{xg}$ for 7 minutes. CRP and calprotectin were analysed directly in freshly collected samples. Remainder of each sample was frozen and analysed later for IL-6, TNF-a, and procalcitonin.

\section{Biomarker analysis}

Calprotectin was measured in plasma samples with particle enhanced turbidimetric method (Gentian Diagnostics, Moss, Norway) on a BS 280 Instrument (Mindray, Shenzhen, China). Reagents, controls and calibrators for calprotectin come from Gentian Diagnostics. The method for analysis of calprotectin has been verified on Cobas c111 and Cobas c501 (Roche Diagnostics). Assay performance were checked using the manufacturer's control materials on two levels.

CRP was analyzed using the COBAS c501 @ system (Roche Diagnostics, Mannheim, Germany), using the CFAS-calibrator and Roche Modular ${ }^{\circledR}$ reagent. Assays were checked using the manufacturer's control materials on two levels. Procalcitonin, IL- 6 and TNF-a were analyzed by sandwich ELISAs (DY8350, DY206, and DY210, R\&D Systems, Minneapolis, MN, USA). The total coefficients of variation for the ELISA methods were approximately $6-7 \%$. All assays were performed blinded without knowledge of clinical information.

\section{Statistics}

All nonparametric statistics analyzes were performed using Analys-it for Excel and data displayed as mean $+/-95 \% \mathrm{Cl}$. Single-sample confidence interval estimation was performed using the formula: $\mu=M \pm$ $t(s M) . M=$ sample mean, $t=t$ statistic determined by confidence level, $s M=$ standard error $=\sqrt{ }(s 2 / n)$. Onetailed t-test for 2 dependent means was used to calculate the difference between paired observations.

\section{Results}

Patient characteristics and early kinetics of calprotectin and CRP in plasma. Plasma samples were initially collected from 20 patients (18 men, age 41-79, 2 women, age 54-69), undergoing elective uncomplicated hernia repair with laparoscopic $(n=6)$ or open technique $(n=14)$, and without signs of inflammatory disease (CRP $<5 \mathrm{mg} / \mathrm{L}$ ) at entry of study. Patients could leave the study at any time point. 2 of the initial 20 patients declined further participation in the study after the first preoperative sampling, and one patient was excluded from further participation because of hemolysis of presurgical blood sample, resulting in 17 patients to be finally included in the study (preoperative and at least one postoperative blood sample). Study samples for calprotectin and CRP were at $2 \mathrm{~h}$ obtained from 17 patients, at $4 \mathrm{~h}$ from 16 patients, at $6 \mathrm{~h}$ from 3 patients, and at 24-26 h from 9 patients. For analysis of IL-6, TNF-a, and procalcitonin samples from one patient were excluded because of sample freezing after 
shelf-life (24 $\mathrm{h}$ at room temperature). This resulted in study samples for IL-6, TNF-a, and procalcitonin being collected from 16 patients at $2 \mathrm{~h}, 15$ patients at $4 \mathrm{~h}, 3$ patients at $6 \mathrm{~h}$, and 8 patients at $24-36 \mathrm{~h}$.

Obtaining a full series of blood samples from all the patients was hampered by the elective surgery patients being discharged early from the hospital at the time of stabilized condition, with subsequent samples requiring their active return to the hospital.

Calprotectin levels in plasma were rapidly and significantly $(p=0.02532)$ elevated within $2 \mathrm{~h}$ following mild inflammatory response associated with inguinal hernia surgery, and continued to be elevated at all later time points analyzed, to reach the highest levels at the $24-36 \mathrm{~h}$ time point (Table 1 and Fig. 1). IL-6 was found to be very transiently elevated $4 \mathrm{~h}$ postsurgery $(p=0.03098)$. CRP, on the other hand, remained within the normal reference levels 2,4 , and 6 h postsurgery, and was elevated $(p=0.00142)$ first at $24-36$ h. No significant increase was observed at any analyzed time point postsurgery for TNF-a or procalcitonin (Table 1, 2 Fig. 1).

One patient had resurgery because of postsurgical bleeding, but interestingly his calprotectin level was not higher than reference interval $(0-1.39 \mathrm{mg} / \mathrm{L})$ at the $24 \mathrm{~h}(0.61 \mathrm{mg} / \mathrm{L})$, at a time point when CRP was slightly elevated $16 \mathrm{mg} / \mathrm{L}$ (reference interval $<5 \mathrm{mg} / \mathrm{L}$ ). 
Table 1

Results of one-tailed t-test for 2 dependent means

\begin{tabular}{|c|c|c|c|c|c|c|c|c|c|}
\hline Analysis & $\begin{array}{l}\text { Sample } \\
\text { at time } \\
\text { point } \\
\text { (h) }\end{array}$ & $\begin{array}{l}\text { Mean } \\
(M)\end{array}$ & SD & $\mathbf{N}$ & $\begin{array}{l}\text { Difference } \\
\text { (Diff - M) }\end{array}$ & Sq. Dev & $t$ & df & $\mathbf{P}$ \\
\hline \multirow{6}{*}{$\begin{array}{l}\text { P- } \\
\text { Calprotectin }\end{array}$} & $\mathrm{Oh}$ & 0.58 & 0.34 & 17 & 0.41 & 10.42 & 2.11 & 16 & $0.02532^{*}$ \\
\hline & $2 \mathrm{~h}$ & 0.99 & 0.84 & & & & & & \\
\hline & Oh & 0.58 & 0.35 & 16 & 0.28 & 3.28 & 2.43 & 15 & $0.01410 *$ \\
\hline & $4 \mathrm{~h}$ & 0.86 & 0.56 & & & & & & \\
\hline & Oh & 0.56 & 0.26 & 9 & 1.02 & 7.50 & 3.15 & 8 & $0.00233^{*}$ \\
\hline & $24-36 h$ & 1.58 & 1.09 & & & & & & \\
\hline \multirow[t]{6}{*}{ P-CRP } & Oh & 0.85 & 0.67 & 17 & -0.03 & 0.9 & -0.51 & 16 & 0.30760 \\
\hline & $2 \mathrm{~h}$ & 0.82 & 0.57 & & & & & & \\
\hline & Oh & 0.88 & 0.67 & 16 & 0.04 & 1.72 & 0.44 & 15 & 0.33194 \\
\hline & $4 \mathrm{~h}$ & 0.92 & 0.62 & & & & & & \\
\hline & Oh & 0.98 & 0.57 & 9 & 5.98 & 143.12 & 4.24 & 8 & $0.00142^{*}$ \\
\hline & $24-36 h$ & 6.96 & 4.33 & & & & & & \\
\hline \multirow[t]{6}{*}{ P-IL-6 } & $\mathrm{Oh}$ & 105 & 210 & 16 & -0.31 & 13493.44 & -0.04 & 15 & 0.48365 \\
\hline & $2 \mathrm{~h}$ & 105 & 185 & & & & & & \\
\hline & Oh & 108 & 217 & 15 & 24.13 & 29719.73 & 2.03 & 14 & $0.03098 *$ \\
\hline & $4 \mathrm{~h}$ & 132 & 209 & & & & & & \\
\hline & Oh & 171 & 284 & 8 & -12 & 8316 & -0.98 & 7 & 0.17878 \\
\hline & $24-36 h$ & 159 & 262 & & & & & & \\
\hline \multirow[t]{6}{*}{ P-TNF-a } & Oh & 53 & 84 & 16 & -2.81 & 836.44 & -1.51 & 15 & 0.07635 \\
\hline & $2 \mathrm{~h}$ & 50 & 81 & & & & & & \\
\hline & Oh & 55 & 86 & 15 & -0.27 & 1794.93 & -0.09 & 14 & 0.46431 \\
\hline & $4 \mathrm{~h}$ & 55 & 87 & & & & & & \\
\hline & Oh & 65 & 104 & 8 & 2.88 & 1294.88 & 0.60 & 7 & 0.28437 \\
\hline & 24-36h & 68 & 115 & & & & & & \\
\hline
\end{tabular}

*The results were considered significant at $p<0.05$. 


\begin{tabular}{|llllllllll|}
\hline Analysis & $\begin{array}{l}\text { Sample } \\
\text { at time } \\
\text { point } \\
\text { (h) }\end{array}$ & $\begin{array}{l}\text { Mean } \\
\text { (M) }\end{array}$ & SD & $\mathbf{N}$ & $\begin{array}{l}\text { Difference } \\
\text { (Diff - M) }\end{array}$ & Sq. Dev & t & df & P \\
\hline $\begin{array}{l}\text { P- } \\
\text { Procalcitonin }\end{array}$ & Oh & 0.55 & 0.68 & 16 & -0.01 & 0.73 & -0.11 & 15 & 0.45746 \\
& $2 \mathrm{~h}$ & 0.54 & 0.67 & & & & & & \\
\cline { 2 - 9 } & Oh & 0.55 & 0.70 & 15 & 0 & 0.06 & 0.11 & 14 & 0.45525 \\
& 4h & 0.55 & 0.72 & & & & & & \\
& Oh & 0.72 & 0.74 & 8 & 0.02 & 0.2 & 0.27 & 7 & 0.39927 \\
\hline & 24-36h & 0.74 & 0.75 & & & & & \\
\hline
\end{tabular}

$6 \mathrm{~h}$ - the sample size is too small to allow a reliable calculation of the t statistic. 
Table 2

Calprotectin, CRP, IL-6, TNF- $a$ and procalcitonin mean $+/-95 \% \mathrm{Cl}$ values within [ in plasma before start of the surgery, and 2, 4, 6 and 24-36 hours after the start of surgery.

\begin{tabular}{|c|c|c|c|c|c|}
\hline $\begin{array}{l}\text { Sample at } \\
\text { timepoint (h) }\end{array}$ & $\begin{array}{l}\text { Calprotectin } \\
\text { (mg/L) }\end{array}$ & $\begin{array}{l}\text { CRP } \\
(\mathrm{mg} / \mathrm{L})\end{array}$ & $\begin{array}{l}\mathrm{IL}-6 \\
\mathrm{ng} / \mathrm{L}\end{array}$ & $\begin{array}{l}\text { TNF-a } \\
\mathrm{ng} / \mathrm{L}\end{array}$ & $\begin{array}{l}\text { Procalcitonin } \\
\mathrm{ng} / \mathrm{L}\end{array}$ \\
\hline 0 & $\begin{array}{l}0.58,95 \% \mathrm{Cl} \\
{[0.41,0.75]}\end{array}$ & $\begin{array}{l}0.85,95 \% \mathrm{Cl} \\
{[0.51,1.20]}\end{array}$ & $\begin{array}{l}105,95 \% \mathrm{Cl} \\
{[-6.9,216.9]}\end{array}$ & $\begin{array}{l}53,95 \% \\
\mathrm{Cl} \\
{[8.24} \\
97.76]\end{array}$ & $\begin{array}{l}0.55,95 \% \mathrm{Cl} \\
{[0.19,0.91]}\end{array}$ \\
\hline 2 & $\begin{array}{l}0.99,95 \% \mathrm{Cl} \\
{[0.56,1.42]}\end{array}$ & $\begin{array}{l}0.82,95 \% \mathrm{Cl} \\
{[0.53,1.11]}\end{array}$ & $\begin{array}{l}105,95 \% \mathrm{Cl} \\
{[6.42,203.58]}\end{array}$ & $\begin{array}{l}50,95 \% \\
\mathrm{Cl} \\
{[6.84} \\
93.16]\end{array}$ & $\begin{array}{l}0.54,95 \% \mathrm{Cl} \\
{[0.18,0.90]}\end{array}$ \\
\hline 4 & $\begin{array}{l}0.86,95 \% \mathrm{Cl} \\
{[0.56,1.16]}\end{array}$ & $\begin{array}{l}0.92,95 \% \mathrm{Cl} \\
{[0.59,1.25]}\end{array}$ & $\begin{array}{l}132,95 \% \mathrm{Cl} \\
{[16.26,247.74]}\end{array}$ & $\begin{array}{l}55,95 \% \\
\mathrm{Cl} \\
{[6.82} \\
103.18]\end{array}$ & $\begin{array}{l}0.55,95 \% \mathrm{Cl} \\
{[0.15,0.95]}\end{array}$ \\
\hline 6 & $\begin{array}{l}0.81,95 \% \mathrm{Cl} \\
{[-0.71,2.33]}\end{array}$ & $\begin{array}{l}0.77,95 \% \mathrm{Cl} \\
{[-0.22,1.76]}\end{array}$ & $\begin{array}{l}113,95 \% \mathrm{Cl} \\
{[-222.36} \\
448.36]\end{array}$ & $\begin{array}{l}120,95 \% \\
\mathrm{Cl} \\
{[-252.62,} \\
492.62]\end{array}$ & $\begin{array}{l}0.61,95 \% \mathrm{Cl} \\
{[-0.93,2.15]}\end{array}$ \\
\hline $24-36$ & $\begin{array}{l}1.58,95 \% \mathrm{Cl} \\
{[0.74,2.42]}\end{array}$ & $\begin{array}{l}6.96,95 \% \mathrm{Cl} \\
{[3.63,10.29]}\end{array}$ & $\begin{array}{l}159,95 \% \mathrm{Cl} \\
{[-60.04,378.04]}\end{array}$ & $\begin{array}{l}68,95 \% \\
\mathrm{Cl} \\
{[-28.14} \\
164.14]\end{array}$ & $\begin{array}{l}0.74,95 \% \mathrm{Cl} \\
{[0.11,1.37]}\end{array}$ \\
\hline
\end{tabular}

\section{Discussion}

The aim of the present study was to determine the early kinetics of calprotectin in plasma following a standardized temporary mild inflammatory response in comparison with other clinically used acute phase markers, using uncomplicated inguinal hernia surgery as a model. Calprotectin levels in plasma were rapidly and significantly elevated (within $2 \mathrm{~h}$ following mild inflammatory response associated with inguinal hernia surgery, remained elevated at later time points and reaching the highest level $(1.58 \mathrm{mg} / \mathrm{L})$ 24-36 $\mathrm{h}$ postsurgery. This contrasts to IL-6 and CRP, for which an elevation was found only later, with a transient elevation at $4 \mathrm{~h}$ postsurgery for IL-6, and an even later elevation for CRP in the 24-36 $\mathrm{h}$ postsurgery samples. Calprotectin also differs from response of TNF-a, and procalcitonin for which no significant increase at all was observed at any analysed time point after surgery. This is in line with known kinetics of CRP following induction of inflammation/infection [20,21]. The increase of calprotectin observed at least several hours prior to increase in CRP, as well as the stable elevation at least the first 24-36 h post induction of an inflammatory response may be of importance for early 
detection and assessment of inflammatory/infectious conditions. The rapid response of calprotectin may be due to the fact that calprotectin is stored in the neutrophils and can be released immediately without any de novo synthesis of the protein. Together with previous findings of calprotectin elevation in inflammatory and infectious conditions $[6,13,15,16,17]$ our results support the use of calprotectin as a biomarker for inflammation/infection. Calprotectin concentration slowly increases during the first 2-36 $\mathrm{h}$ after surgery, demonstrating that calprotectin concentration doesn't exhibit short $(<24-36 \mathrm{~h}$ ) peaks of elevation, indicating that there is no short "diagnostic window" for calprotectin to detect developing infections or inflammations with a marked neutrophil activation, e.g. severe bacterial infections/sepsis. Furthermore, observations from this study indicate that calprotectin can be useful for detection of early postoperative infections since the levels are not significantly increased above normal reference range by the surgery itself.

Further studies on calprotectin kinetics are required to establish the full kinetics of calprotectin following induction of inflammation/infection, in order to reveal the response to various sources of induction of inflammation/infection and to gain knowledge also of the later part of the kinetics.

\section{Conclusions}

Calprotectin levels in plasma were rapidly elevated (within $2 \mathrm{~h}$ following mild inflammatory response associated with inguinal hernia surgery and continued to increase at later time points (24-36 h). Increase of calprotectin was observed several hours prior to increase in IL-6 or CRP. However, during the first $24 \mathrm{~h}$ the levels induced by the mild inflammatory response caused by inguinal hernia surgery were not significantly exceeding the normal reference range, suggesting that calprotectin can be useful for early detection of postsurgical infections.

\section{Declarations}

\section{Ethical approval and Consent to participate}

The study was approved by the Uppsala Regional Ethics Committee, Uppsala, Sweden (Dnr 2018 / 227). All parts of the study were performed in accordance with the ethical approval and Swedish and European regulations. All participants gave informed consent prior to inclusion in the study.

\section{Consent for publication}

Not applicable.

\section{Availability of data and materials}

The datasets used and/or analysed during the current study are available from the corresponding author (A.L.) on reasonable request.

\section{Competing interests}


Aleksandra M. Havelka is employed by Gentian Diagnostics AB, Stockholm, Sweden. Other authors declare no competing interests.

\section{Funding}

Open access funding provided by Uppsala University.

\section{Authors' contributions}

A.M.H., P.S.S. and K.S. have designed the study and participated in the interpretation of the results. K.S. has performed the majority of the experiments, performed statistical analysis and drafted the manuscript. A.M.H and P.S.S. assisted in performing the experiments and in the writing of the manuscript. A.L. supervised the study, participated in the interpretation of the results as well as in the writing of the manuscript. All authors reviewed the manuscript.

\section{Acknowledgements}

Not applicable.

\section{References}

1. The World health report 2000-health systems: improving performance. 2020; https://www.who.int/whr/2000/en/.

2. Dupuy AM, Philippart F, Péan Y, Lasocki S, Charles PE, Chalumeau M, et al. Role of biomarkers in the management of antibiotic therapy: an expert panel review: I - currently available biomarkers for clinical use in acute infections. Ann Intensive Care. 2013;3:22. doi:10.1186/2110-5820-3-22.

3. Versporten A, Zarb P, Caniaux I, Gros MF, Drapier N, Miller M, et al. Antimicrobial consumption and resistance in adult hospital inpatients in 53 countries: results of an internet-based global point prevalence survey. Lancet Glob Health. 2018;6:e619-29. doi:10.1016/S2214-109X(18)30186-4.

4. Spellberg B, Gilbert DN. The future of antibiotics and resistance: a tribute to a career of leadership by John Bartlett. Clin Infect Dis. 2014;59(Suppl 2):71-5. doi:10.1093/cid/ciu392.

5. Xu S, Venge P. Lipocalins as biochemical markers of disease. Biochim Biophys Acta. 2000;1482:298-307. doi:10.1016/s0167-4838(00)00163-1.

6. Havelka A, Sejersen K, Venge P, Pauksens K, Larsson A. Calprotectin, a new biomarker for diagnosis of acute respiratory infections. Sci Rep. 2020;10:4208. doi:10.1038/s41598-020-61094-z.

7. Schenten V, Plançon S, Jung N, Hann J, Bueb JL, Bréchard S, et al. Secretion of the Phosphorylated Form of S100A9 from Neutrophils Is Essential for the Proinflammatory Functions of Extracellular S100A8/A9. Front Immunol. 2018;9:447. doi:10.3389/fimmu.2018.00447.

8. Chan JK, Roth J, Oppenheim JJ, Tracey KJ, Vogl T, Feldmann M, et al. Alarmins: awaiting a clinical response. J Clin Invest. 2012;122:2711-9. doi:10.1172/JCI62423. 
9. Vogl T, Tenbrock K, Ludwig S, Leukert N, Ehrhardt C, van Zoelen MA, et al. Mrp8 and Mrp14 are endogenous activators of Toll-like receptor 4, promoting lethal, endotoxin-induced shock. Nat Med. 2007;13:1042-9. doi:10.1038/nm1638.

10. Ehrchen JM, Sunderkötter C, Foell D, Vogl T, Roth J. The endogenous Toll-like receptor 4 agonist S100A8/S100A9 (calprotectin) as innate amplifier of infection, autoimmunity, and cancer. J Leukoc Biol. 2009;86:557-66. doi:10.1189/jlb.1008647.

11. Berthier S, Paclet MH, Lerouge S, Roux F, Vergnaud S, Coleman AW, et al. Changing the conformation state of cytochrome b558 initiates NADPH oxidase activation: MRP8/MRP14 regulation. J Biol Chem. 2003;278:25499-508. doi:10.1074/jbc.M209755200.

12. Schenten V, Bréchard S, Plançon S, Melchior C, Frippiat JP, Tschirhart EJ. iPLA2, a novel determinant in Ca2+- and phosphorylation-dependent S100A8/A9 regulated NOX2 activity. Biochim Biophys Acta. 2010;1803:840-7. doi:10.1016/j.bbamcr.2010.02.006.

13. Choi IY, Gerlag DM, Herenius MJ, Thurlings RM, Wijbrandts CA, Foell D, et al. MRP8/14 serum levels as a strong predictor of response to biological treatments in patients with rheumatoid arthritis. Ann Rheum Dis. 2015;74:499-505. doi:10.1136/annrheumdis-2013-203923.

14. Menees SB, Powell C, Kurlander J, Goel A, Chey WD. A meta-analysis of the utility of C-reactive protein, erythrocyte sedimentation rate, fecal calprotectin, and fecal lactoferrin to exclude inflammatory bowel disease in adults with IBS. Am J Gastroenterol. 2015;110:444-54. doi:10.1038/ajg.2015.6.

15. Foell D, Roth J. Proinflammatory S100 proteins in arthritis and autoimmune disease. Arthritis Rheum. 2004;50:3762-71. doi:10.1002/art.20631.

16. Huang L, Li J, Han Y, Zhao S, Zheng Y, Sui F, Xin X, Ma W, Jiang Y, Yao Y, Li W. Serum Calprotectin Expression as a Diagnostic Marker for Sepsis in Postoperative Intensive Care Unit Patients. J Interferon Cytokine Res. 2016;36:607-16. doi:10.1089/jir.2016.0037.

17. Simm M, Söderberg E, Larsson A, Castegren M, Nilsen T, Eriksson M, et al. Performance of plasma calprotectin as a biomarker of early sepsis: a pilot study. Biomark Med. 2016;10:811-8. doi:10.2217/bmm-2016-0032.

18. Jukić M, Pogorelić Z, Šupe-Domić D, Jerončić A. Comparison of inflammatory stress response between laparoscopic and open approach for pediatric inguinal hernia repair in children. Surg Endosc. 2019;33:3243-50. doi:10.1007/s00464-018-06611-y.

19. Sido B, Teklote JR, Hartel M, Friess H, Büchler MW. Inflammatory response after abdominal surgery. Best Pract Res Clin Anaesthesiol. 2004;18:439-54. doi:10.1016/j.bpa.2003.12.006.

20. Nakayama T, Sonoda S, Urano T, Yamada T, Okada M. Monitoring both serum amyloid protein A and C-reactive protein as inflammatory markers in infectious diseases. Clin Chem. 1993;39:293-7. PMID: 8381732.

21. Barbić J, Ivić D, Alkhamis T, Drenjancević D, Ivić J, Harsanji-Drenjancević I, et al. Kinetics of changes in serum concentrations of procalcitonin, interleukin-6, and C- reactive protein after elective 
abdominal surgery. Can it be used to detect postoperative complications? Coll Antropol. 2013;37:195-201. PMID: 23697273.

Figures

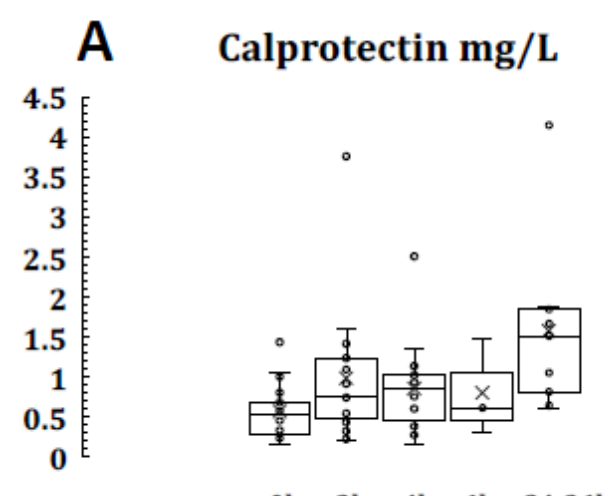

Oh 2h 4h $\quad 6 h \quad 24-36 h$

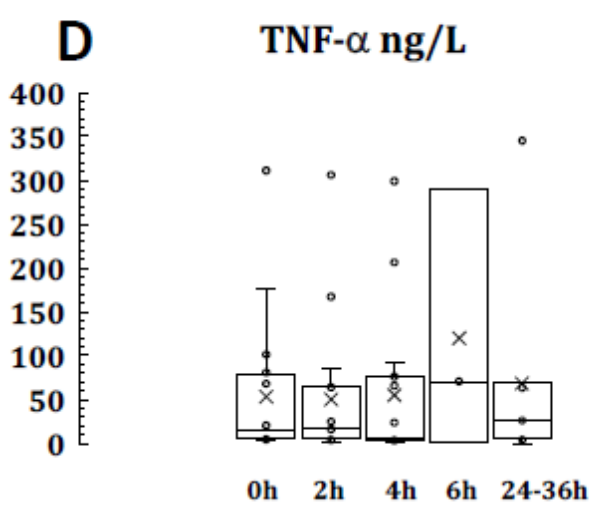

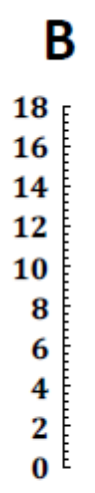

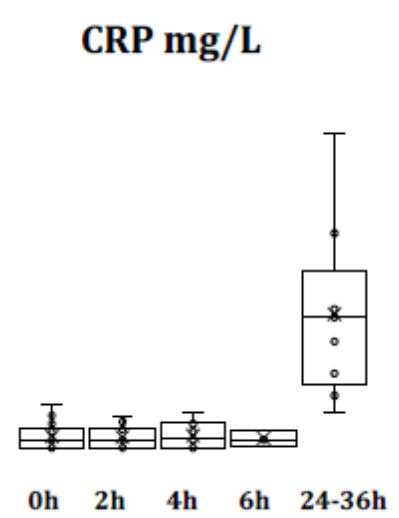

IL-6 ng/L
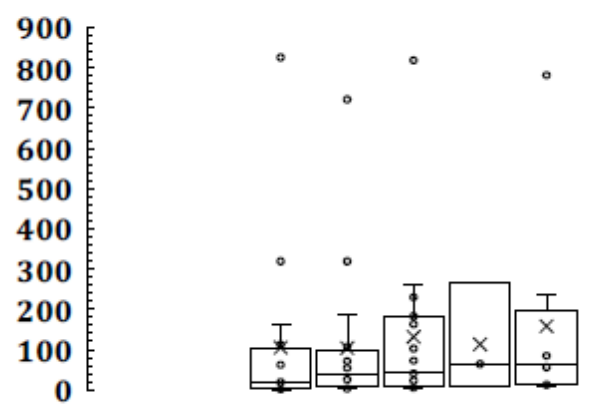

0h $2 \mathrm{~h} \quad 4 \mathrm{~h} \quad 6 \mathrm{~h} \quad 24-36 \mathrm{~h}$

\section{Figure 1}

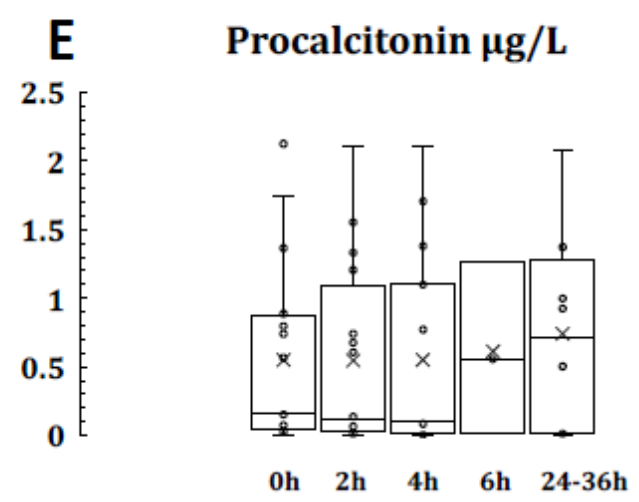

Early kinetics of calprotectin (A), CRP (B), IL-6 (C), TNF-a(D), and procalcitonin (E) in plasma following inguinal hernia surgery (before start of the surgery, and 2, 4, 6 and 24-36 hours after the start of surgery). * Indicates statistical significance $(p<0.05)$. 